\title{
The Guest Satisfaction Acceleration Strategy Based on Importance Performance Analysis of Solaris Hotel Kuta, Bali, Indonesia
}

\author{
I Made Yoga Ary Sadewa ${ }^{1}$, Ni Luh Eka Armoni ${ }^{2}$, Nyoman Mastiani Nadra ${ }^{3}$, K Ketut Suja ${ }^{4}$, \\ I Gusti Bagus Rai Utama \\ ${ }^{1.2,3,4}$ Bali State Polytechnic, Indonesia \\ ${ }^{5}$ Dhyana Pura University, Bali, Indonesia
}

\begin{abstract}
This research was conducted to determine the quality of service in increasing guest satisfaction at Hotel Solaris Kuta, service quality has five dimensions which include direct evidence (tangible), reliability (reliability), responsiveness (responsiveness), assurance (assurance), and empathy (empathy). The author uses research methods with data collection tools in the form of observation, questionnaires, and documentation. The sampling technique used accidental sampling, the sample used in this study amounted to 51 respondents. The data obtained comes from distributing questionnaires that have been tested with validity and reliability. The analysis techniques used in this study are servqual (Service Quality), IPA (Importance Performance Analysis). The results showed that the gap between positive and neutral servqual scores was more than the negative score gap, so it could be seen that the service quality of room attendants at Hotel Solaris Kuta had shown good service. Several indicators must be improved in terms of service quality, namely indicators of complete room facilities (Q1), room attendants who are neat and clean (Q3), and room attendants who are polite to guests $(\mathrm{Q} 13)$. Meanwhile, indicators that need to be maintained for service quality are room attendants in keeping rooms looking clean $(\mathrm{Q} 2)$, room attendants in paying attention to guest needs (Q4), room attendants' readiness in serving guests $(\mathrm{Q} 7)$, room attendants responding to complaints and wishes of guests $(\mathrm{Q} 9)$.
\end{abstract}

KEYWORDS: Guest Satisfaction, Importance Performance, Room Attendant, Service Quality.

\section{INTRODUCTION}

Bali as one of the islands in Indonesia which is famous for its tourism due to its natural beauty, unique culture, and the friendliness of the Balinese people to foreign and domestic tourists makes Bali one of the tourist destinations that are in great demand by tourists. During this pandemic, Bali is one of the islands that has been the most affected, the lack of tourists visiting Bali has caused many facilities to close, one of which is accommodation facilities which have the biggest impact.

Solaris Kuta is a 3-star hotel located in Kuta, located in a strategic area 5 minutes from the airport as well as a well-known tourist center, giving rise to fierce and strong business competition in attracting tourists to stay at the hotel.

A hotel is an effort to provide accommodation in the form of rooms in a building, which can be equipped with food and beverage services, entertainment activities, and or other facilities daily to make a profit (Tarmoezi, 2000). the sections contained in the hotel in general are as follows (1) Front Office, (2) Housekeeping, (3) Food and Beverage, (4) Marketing, and Sales, (5) Finance, (6) Human Resource Department, (7) Engineering, (8) Security (Sulastiyono, 2011)

One of the sections that deal directly with guests is the Room Attendant which is included in the Housekeeping department, Housekeeping also means the part that is in charge and responsible for maintaining cleanliness, tidiness, beauty, and comfort throughout the hotel area, both outside the building and inside the building, including rooms. - guest rooms, rooms rented by guests, restaurants, offices, and toilets (Rumekso, 2002). In addition, the room attendant is a guest room officer who has the responsibility to maintain the cleanliness, tidiness, and completeness of the room (Sulistiyono, 2001).

The quality of service provided must always be the best, service quality is the service, people, processes, and environment that meet or exceed expectations. Also referred to as something related to the fulfillment of customer expectations/needs, where service is said to be of quality if it can provide products and services (services) by customer needs and expectations (Hardiansyah, 2011), thus satisfaction is an attitude that is decided based on the experience gained. Satisfaction is an assessment of the characteristics or features of a product or service, or the product itself, which provides a level of consumer pleasure related to meeting consumer consumption needs (Lovelock and Wirtz, 2011). 


\section{International Journal of Current Science Research and Review}

ISSN: 2581-8341

Volume 05 Issue 01 January 2022

DOI: 10.47191/ijesrr/V5-i1-15, Impact Factor: 5.825

IJCSRR@ 2022

WWw.ijcsrr.org

\section{METHODOLOGY}

This research was conducted at the Hotel Solaris Kuta for 5 months. This research was conducted at the Housekeeping Department which focuses on the room attendant section where the object studied is how the quality of service can affect the level of guest satisfaction at the Hotel Solaris Kuta. Variable identification is an attribute, nature, or value of a person, object, or activity that has a certain variation set by researchers to study and draw conclusions (Sugiyono, 2014). Therefore, the attributes to be studied have 5 dimensions based on the dimensions of service quality, namely Tangible, Reliability, Responsiveness, Assurance, Empathy (Utama, 2015, 2017) can be seen in the table below.

Table 1. Dimensions and indicators of service quality

\begin{tabular}{|ll|}
\hline \multicolumn{1}{|c|}{ Dimension } & Indicator \\
\hline Tangible & - Complete in-room facilities \\
& - Room area looks clean \\
& - Cleanliness and neatness of Room Attendant Attendant \\
\hline Reliability & - Room Attendant's level of attention in understanding guests \\
& - Room Attendant can clean the room quickly and right \\
& - Room Attendant serves guest problems \\
\hline Responsiveness & - The readiness of the room attendant in serving guests \\
& - Room Attendant provides clear information and easy to understand \\
& - Room Attendant responds to guest complaints and wishes \\
\hline Assurance & - Room Attendant provides a sense of security for service which are given \\
\hline Empathy & - Room Attendant provides maximum service \\
\hline & - Room Attendant pays special attention to guests \\
& - Room Attendant is polite to guests \\
\hline
\end{tabular}

The types of data used in this study are quantitative data and qualitative data. Quantitative data is data in the form of numbers or qualitative data that is numbered and qualitative data is data in the form of words, sentences, schemes, and pictures (Sugiyono, 2013). Sources of data used in this study are primary data and secondary data. Primary Data is data that is directly given to data collectors (Sugiyono, 2016) Secondary data is data that is not given directly to data collectors called secondary data (Sugiyono, 2018)

In this study, in determining the sample, the researcher used the accidental sampling technique (Sugiyono, 2009). The determination of the number of samples in this study used the Slovin technique (Sugiyono, 2011). Therefore, in this study, the sample was set to 51 .

The data analysis technique used is Validity Test, Reliability Test, Servqual Test, and Important Performance Analysis, validity is the degree of accuracy between data that occurs in the object of research and data that can be reported by researchers (Sugiyono, 2014), reliability testing is intended to find out the consistency of measuring instruments in their use, or in other words, these measuring instruments have consistent results when used multiple times at different times (Sugiyono, 2012). The servqual model is based on the assumption that consumers compare the service performance of relevant attributes with ideal/perfect standards for each service attribute (Tjiptono, 2012), this technique, respondents are asked to rank various elements (attributes) of the offering based on the degree of importance of each element. (Daryanto and Setyobudi, 2014).

\section{RESULTS AND DISCUSSIONS}

\section{A. Servqual Calculation}

The calculation of the Servqual Test that has been carried out, shows how the quality of service at Solaris Hotel Kuta is. If the indicator shows negative (-) then the quality of service has a gap or can be said to be unsatisfactory. If the indicator shows a positive $(+)$ or neutral (0) score, it can be said that the service quality is satisfactory. Table 2 shows the Servqual score of each indicator 


\section{International Journal of Current Science Research and Review}

ISSN: 2581-8341

Volume 05 Issue 01 January 2022

DOI: 10.47191/ijesrr/V5-i1-15, Impact Factor: 5.825

IJCSRR @ 2022

Table 2. Results of Servqual Calculation.

\begin{tabular}{|c|c|c|c|c|c|}
\hline No & Attribute & $\mathrm{P}$ & $\mathrm{E}$ & GAP & Exp \\
\hline \multicolumn{6}{|c|}{ Tangible } \\
\hline Q1 & Room facilities complete & 4,31 & 4,35 & $-0,04$ & Negative \\
\hline Q2 & Room attendants keep the room clean & 4,45 & 4,45 & 0 & Neutral \\
\hline Q3 & The room Attendant is neat and clean & 4,41 & 4,41 & 0 & Neutral \\
\hline \multicolumn{6}{|c|}{ Reliability } \\
\hline Q4 & $\begin{array}{l}\text { Room Attendant in paying attention to guest } \\
\text { needs }\end{array}$ & 4,53 & 4,35 & 0,18 & Positive \\
\hline Q5 & $\begin{array}{l}\text { The Room Attendant can clean the room quickly } \\
\text { and precisely }\end{array}$ & 4,41 & 4,31 & 0,10 & Positive \\
\hline Q6 & Room Attendant can serve guest problems & 4,43 & 4,21 & 0,22 & Positive \\
\hline \multicolumn{6}{|c|}{ Responsiveness } \\
\hline Q7 & Room Attendant alacrity in serving guests & 4,45 & 4,35 & 0,10 & Positive \\
\hline Q8 & Room Attendant able to give information & 4,41 & 4,30 & 0,11 & Positive \\
\hline Q9 & $\begin{array}{l}\text { Room Attendant responds to guest complaints } \\
\text { and wishes }\end{array}$ & 4,50 & 4,45 & 0,5 & Positive \\
\hline \multicolumn{6}{|c|}{ Assurance } \\
\hline Q10 & $\begin{array}{l}\text { Room Attendant provides a sense of security for } \\
\text { the services provided }\end{array}$ & 4,41 & 4,31 & 0,10 & Positive \\
\hline Q11 & Room Attendant can provide maximum service & 4,25 & 4,25 & 0 & Neutral \\
\hline \multicolumn{6}{|c|}{ Empathy } \\
\hline Q12 & Room Attendant pays special attention to guests & 4,44 & 4,29 & 0,15 & Positive \\
\hline Q13 & The room Attendant is polite to guests & 4,41 & 4,37 & 0,04 & Positive \\
\hline
\end{tabular}

Based on Table 2, it is found that 8 (eight) indicators have a positive average score, 3 (three) indicators have a neutral average score, and 1 (one) indicator has a negative average score.

\section{B. Validity and Reliability Test of Perception and Expectation}

Table 3. Validity Test Results for Perception and Expectations

\begin{tabular}{|c|c|c|c|c|c|}
\hline \multirow[b]{2}{*}{ Attribute } & \multirow[b]{2}{*}{$\mathrm{R}$} & \multicolumn{2}{|l|}{ Perception } & \multicolumn{2}{|l|}{ Expectation } \\
\hline & & $\begin{array}{l}\text { Total } \\
\text { Correlation }\end{array}$ & Item Explanation & Total Item Correlation & Explanation \\
\hline Q1 & 0,2788 & 0,443 & Valid & 0,546 & Valid \\
\hline Q2 & 0,2788 & 0,403 & Valid & 0,418 & Valid \\
\hline Q3 & 0,2788 & 0,458 & Valid & 0,350 & Valid \\
\hline Q4 & 0,2788 & 0,424 & Valid & 0,528 & Valid \\
\hline Q5 & 0,2788 & 0,411 & Valid & 0,487 & Valid \\
\hline Q6 & 0,2788 & 0,495 & Valid & 0,383 & Valid \\
\hline Q7 & 0,2788 & 0,382 & Valid & 0,649 & Valid \\
\hline Q8 & 0,2788 & 0,483 & Valid & 0,445 & Valid \\
\hline Q9 & 0,2788 & 0,520 & Valid & 0,515 & Valid \\
\hline Q10 & 0,2788 & 0,397 & Valid & 0,414 & Valid \\
\hline Q11 & 0,2788 & 0,476 & Valid & 0,524 & Valid \\
\hline Q12 & 0,2788 & 0,444 & Valid & 0,673 & Valid \\
\hline Q13 & 0,2788 & 0,525 & Valid & 0,455 & Valid \\
\hline
\end{tabular}




\section{International Journal of Current Science Research and Review}

ISSN: 2581-8341

Volume 05 Issue 01 January 2022

DOI: 10.47191/ijesrr/V5-i1-15, Impact Factor: 5.825

IJCSRR@ 2022

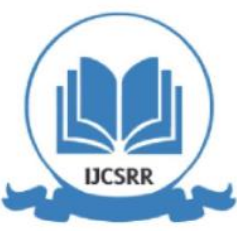

www.ijcsrr.org

Valid decision criteria are stated if the total item correlation value is greater than 0.2788 . Based on the Table 3 output, the total item correlation value for all questionnaire items is greater than 0.2788 therefore all items in the perception and expectation questionnaire regarding service quality are declared valid to be used in this study. After testing the validity and the results of the questionnaire declared valid, then proceed with the reliability test. The reliability of the research instrument was assessed through the magnitude of Cronbach's Alpha coefficient, which shows the internal consistency of the items that underlie a variable. Cronbach's Alpha coefficient calculation using SPSS 26.0 for Windows.

Table 4. Reliability Test Results of Perceived and Expectations

\begin{tabular}{|lllll|}
\hline \multirow{2}{*}{ N of Items } & Perception & \multicolumn{3}{c|}{ Expectation } \\
\cline { 2 - 5 } & Cronbach's Alpha & Description & Cronbach's Alpha & Description \\
\hline 13 & 0.668 & Reliable & 0.735 & Reliable \\
\hline
\end{tabular}

Based on table 4 above, it can be seen that all the coefficients of the tested variable indicators are greater than Cronbach's Alpha greater than 0.60. So these results can indicate that all indicators of the level of perception (x) and level of satisfaction (y) in this study proved reliable. This means that the items used will be able to obtain consistent data in the sense that if the question is asked again, relatively the same answer will be obtained

\section{Importance Performance Analysis}

Important performance analysis is used to determine which service indicators need to be improved and need to be maintained in service to guests by the room attendant at the Hotel Solaris Kuta, which is presented in the form of a Cartesian diagram. The Cartesian diagram consists of four quadrants, quadrant $\mathrm{A}$ is the main priority, which means that the indicators in this quadrant are the indicators that most need to improve their services. Quadrant B shows that the indicators contained in this quadrant already have good service so it is necessary to maintain achievement. Quadrant $\mathrm{C}$ is a low priority, meaning that the indicators in this quadrant have little effect on guest satisfaction. Quadrant D shows that all indicators in this quadrant are considered excessive.

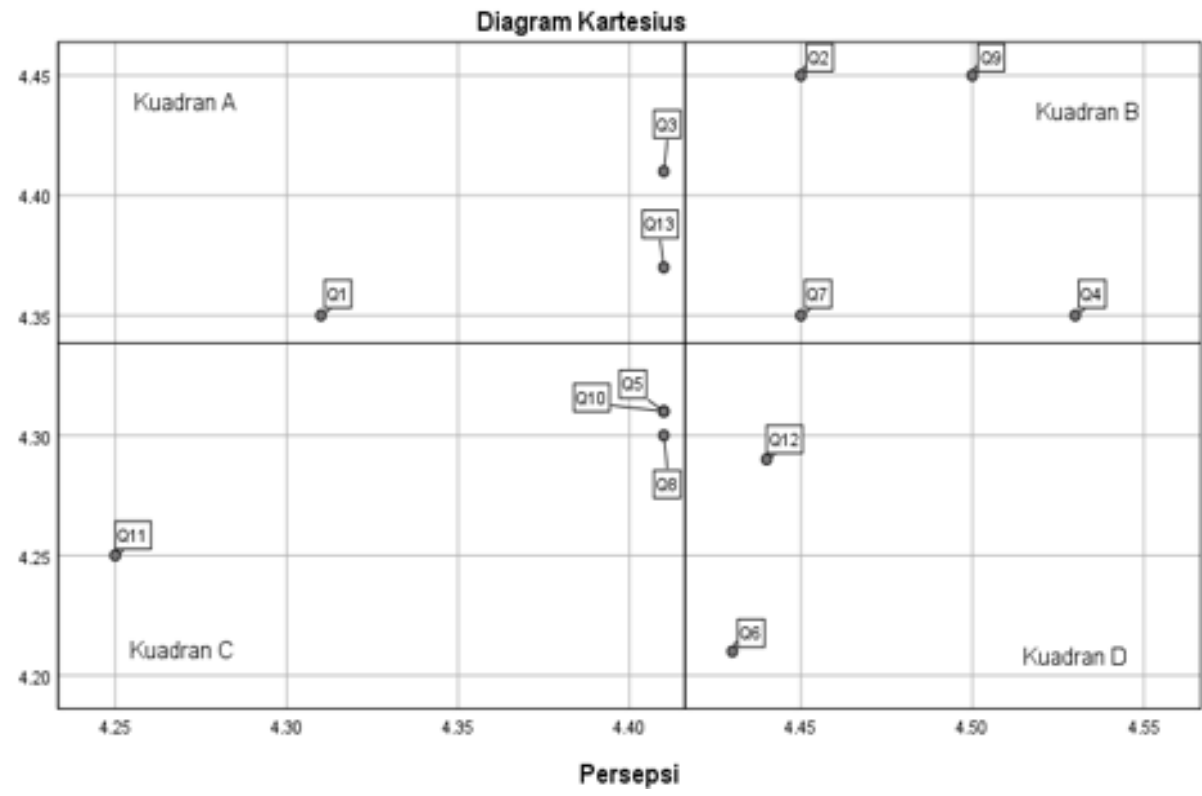

Picture 1. Cartesian Diagram Importance Performance Analysis

Source: SPSS 26.0 Output for Windows, 2021

Based on Figure 2, from the calculation of the importance-performance analysis, it was found that there are 3 indicators in quadrant A, namely complete room facilities (Q1), Room Attendant with a neat and clean appearance (Q3), Room Attendant being 


\section{International Journal of Current Science Research and Review}

ISSN: 2581-8341

\section{Volume 05 Issue 01 January 2022}

DOI: 10.47191/ijcsrr/V5-i1-15, Impact Factor: 5.825

IJCSRR@ 2022

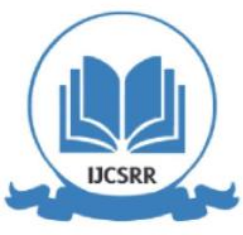

www.ijesrr.org

polite to guests (Q13), 4 indicators on quadrant B, namely Room attendant in keeping the room looking clean (Q2), Room Attendant in paying attention to guest needs (Q4), Room Attendant alertness in serving guests (Q7), Room Attendant responding to guest complaints and wishes (Q9), 4 indicators in quadrant C i.e. Room Attendant can clean the room quickly and accurately (Q5), Room Attendant provides clear and easy-to-understand information (Q8), Room Attendant provides a sense of security for the services provided (Q10), Room Attendant can provide maximum service (Q11), and 2 indicators in quadrant D, namely Room Attendant can serve guest problems (Q6), Room Attendant gives special attention to guests (Q12).

The following are some of the activities carried out by researchers at the object of research, such as cleaning in the basement and sorting laundry.

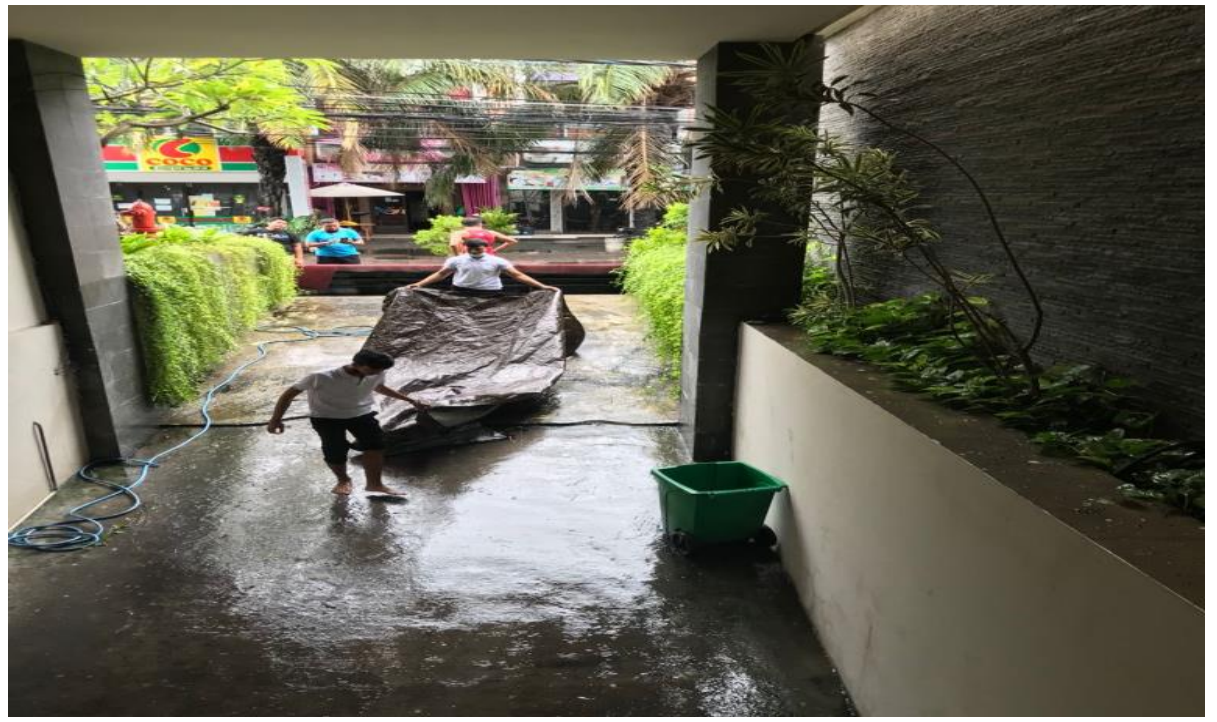

Picture 2. Cleaning The Basement

(Source: researcher's document, 2021)

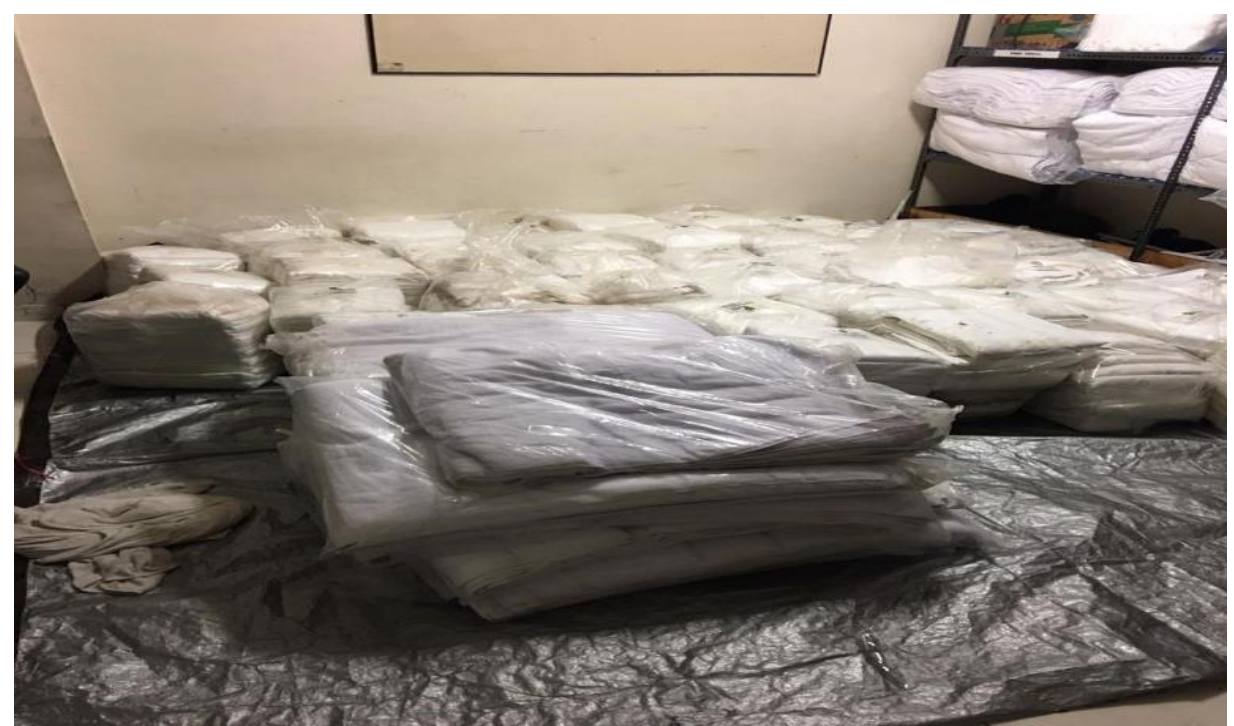

Picture 3. Sorting Laundry

(Source: researcher's document, 2021)

\section{CONCLUSIONS}

Based on the results of the analysis and discussion that has been carried out that the quality of service at the Solaris Kuta Hotel can be said to be good, this is evidenced by the servqual test, it was found that 9 indicators produce a positive gap, 3 indicators that 


\section{International Journal of Current Science Research and Review}

ISSN: 2581-8341

Volume 05 Issue 01 January 2022

DOI: 10.47191/ijesrr/V5-i1-15, Impact Factor: 5.825

IJCSRR@ 2022

WWw.ijesrr.org

produce a neutral gap and 1 indicator that shows a negative gap, From the results of research conducted, it can be seen that customer expectations for perceived service perceptions have been fulfilled so that guests are satisfied with the services provided by the room attendant. The results of the important performance analysis show 3 indicators that indicate the need to improve the performance of the room attendant itself such as indicators of complete room facilities (Q1), room attendants who look neat and clean (Q3), and room attendants are polite to guests (Q13).

\section{REFERENCES}

1) Agus, Sulastiyono. (2011). Manajemen Penyelanggaraan Hotel. Bandung: Alfabeta.

2) Agusnawar. (2000). Operasional tata Graha Hotel: Hotel Housekeeping Operational. Jakarta: Gramedia Pustaka Utama

3) Assauri, Sofjan. 2003. Customer Service yang Baik Landasan Pencapaian Customer Satisfaction. Usahawan, 01

4) Audina, Nia. 2018. Kualitas Pelayanan Room Boy Di Hotel Grand Zuri Pekanbaru Riau. Jurnal Fakultas Sains Solusi dan Sains Politik Universitas Riau JOM FISIP

5) Daryanto, \& Setyobudi, I. (2014). Konsumen dan pelayanan prima. Yogyakarta: Gava Media Djam'an Satori \& Aan Komariah. (2011). Metodologi Penelitian Kualitatif. Bandung: PT Alfabeta.

6) Fitry, H., \& Suyuthie, H. (2017). Analisis Kualitas Pelayanan Room Attendant Di Rocky Plaza Hotel Padang. E-Journal Home Economic and Tourism, 15(2).

7) Hardiansyah. 2011. Kualitas Pelayanan Publik. Yogyakarta: Gava Media

8) Kotler, Philip. 2009. Manajemen Pemasaran, Jilid 2, Edisi 13. Alih Bahasa Benyamin Molan. Jakarta: Prehallindo.

9) Lovelock, C, dan John Wirtz, 2011. "Pemasaran Jasa Perspektif edisi 7". Jakarta: Erlangga.

10) Minh, N. H., Ha, N. T., Anh, P. C., \& Matsui, Y. (2015). Service quality and customer satisfaction: A case study of hotel industry in Vietnam. Asian Social Science, 11(10), 73.

11) Minh, N. H., Ha, N. T., Anh, P. C., \& Matsui, Y. (2015). Service quality and customer satisfaction: A case study of hotel industry in Vietnam. Asian Social Science, 11(10), 73.

12) Nana Syaodih Sukmadinata. (2011). Metode Penelitian Pendidikan. Bandung: PT Remaja Rosdakarya

13) Rumekso, (200). Housekeeping Hotel, Yogyakarta: ANDI.

14) Saleem, H., \& Raja, N. S. (2014). The impact of service quality on customer satisfaction, customer loyalty and brand image: Evidence from the hotel industry of Pakistan. Middle-East Journal of Scientific Research, 19(5), 706-711

15) Saleem, H., \& Raja, N. S. (2014). The impact of service quality on customer satisfaction, customer loyalty and brand image: Evidence from the hotel industry of Pakistan. Middle-East Journal of Scientific Research, 19(5), 706-711.

16) Sugiyono, (2009). Metode Penelitian Kuantitatif Kualitatif Dan R\&D. Bandung: Alfabeta

17) Sugiyono. (2011). Metode Penelitian Kuantitatif, Kualitatif dan R\&D. Bandung: Afabeta

18) Sugiyono. (2014). Metode Penelitian Pendidikan Pendekatan Kuantitatif, Kualitatif, dan R\&D. Bandung: Alfabeta.

19) Sugiyono. (2016). Metode Penelitian. Bandung: Alfabeta.

20) Sugiyono. (2018). Metode Penelitian Kualitatif . Bandung: Alfabeta

21) Sugiyono. 2012. Metode Penelitian Kuantitatif Kualitatif dan R\&B. Bandung: Alfabeta.

22) Sugiyono. 2013. Metode Penelitian : Kuantitatif, Kualitatif, dan R\&D. Bandung: Alfabeta.

23) Sulistiyono (2001:124). room atenden

24) Tarmoezi, T. (2000). Hotel Front Office. Jakarta: Kesaint Blanc

25) Taviprawati, Ervina, Vienna Artina Sembiring, dan Emenina Tarigan. 2019. Analisis Kualitas Pelayanan Room Attendant Terhadap Kepuasan Pelanggan Di Hotel Inter-Continental Jakarta Mid Plaza.

26) Tjiptono, Fandy. 2012. Strategi Pemasaran, edisi ketiga. Yogyakarta: Andi.

27) Utama, I.G.B.R. 2015. Pengantar Industri Pariwisata. Deepublish.

28) Utama, I.G.B.R., 2017. Pemasaran Pariwisata. Penerbit Andi.

Cite this Article: I Made Yoga Ary Sadewa, Ni Luh Eka Armoni, Nyoman Mastiani Nadra, I Ketut Suja, I Gusti Bagus Rai Utama (2022). The Guest Satisfaction Acceleration Strategy Based on Importance Performance Analysis of Solaris Hotel Kuta, Bali, Indonesia. International Journal of Current Science Research and Review, 5(1), 134-139 